\title{
Heterogenization of Copper Catalyst for the Oxidation of Phenol, a Common Contaminant
}

\section{in Industrial Wastewater}

\author{
Isabel U. Castro, ${ }^{a}$ Agustí Fortuny, ${ }^{b}$ Frank Stüber, ${ }^{a}$ Azael Fabregat, ${ }^{a}$ Josep Font, ${ }^{a}$ and Christophe Bengoa ${ }^{a}$ \\ a Departament d'Enginyeria Química, Escola Tècnica Superior d'Enginyeria Química, \\ Universitat Rovira i Virgili, Av. Països Catalans 26, 43007 Tarragona, Spain; christophe.bengoa@urv.cat (for correspondence) \\ ${ }^{\mathrm{b}}$ Departament d'Enginyeria Química, EPSEVG, Universitat Politècnica de Catalunya, Av. Víctor Balaguer s/n, \\ 08800 Vilanova i la Geltrú, Barcelona, Spain
}

Published online 27 February 2012 in Wiley Online Library (wileyonlinelibrary.com). DOI 10.1002/ep.11620

\begin{abstract}
Advance oxidation process was employed as a pretreatment of industrial wastewater. For this purpose, the use of heavy metals as a catalyst is necessary but also complicated because bomogeneous catalysts are difficult to recover after reaction process. The heterogenization of Cu(II) ions was proposed by taking advantage of the adsorptive characteristics of polymeric matrices. Crosslinked poly(4-vinylpyridine) of 2 and 25\% and poly(D-glucosamine) were tested as supports of copper. Adsorption was employed to heterogenize $\mathrm{Cu}(I I)$ by considering the influences of $\mathrm{pH}$ and temperature on the process. The catalysts were evaluated by their metal content, catalytic behavior for the oxidation of phenol and leaching degree after reaction. Poly(4-vinylpyridine) 2\% was the best material for Cu(II) immobilization with an adsorption capacity of $90 \mathrm{mg} \mathrm{g}^{-1}$. Afterward, poly(4-vinylpyridine) 2\%, Cu(II) achieved 64\% of phenol conversion, which represents a favorable result for the oxidation of phenol as the model of industrial wastewater pretreatments. (C) 2012 American Institute of Chemical Engineers Environ Prog, 32: 269-278, 2013

Keywords: poly(4-vinylpyridine), chitosan, copper catalyst, adsorption, phenol removal
\end{abstract}

\section{INTRODUCTION}

The application of conventional homogeneous catalysts becomes complicated in practice due to some problems, which were represented by the catalytic separation after use, catalytic regeneration, etc [1]. To overcome these problems, it was proposed to use heterogeneous catalysts on oxidation processes, also called heterogeneous catalytic systems [1]. Interesting results reported to use transition metals as active phase over zeolites [2], pillared clays [3, 4], or activated carbon as supports [5]. The main problem of these catalysts comes from the leaching of the metals when oxidation was carried out at low $\mathrm{pH}$, below 3. Nowadays, catalyst-based technologies present an optimized activity due to they intend to achieve clean processes without by-products, eliminating the need of waste disposal [6]. For instance, various supports anchor metal complexes, from which polymer supports provide better catalytic activity and selectivity [7]. The catalytic activity of copper ion in

Present address of Isabel U. Castro: CAT Catalytic Center, ITMC, RWTH Aachen University, Worringerweg 1, 52074 Aachen, Germany.

(C) 2012 American Institute of Chemical Engineers peroxide activation was dramatically enhanced by complexation with pyridine, organic acids, amino acids, and other chelating acids [8]. Therefore, Cu(II) was selected as catalyst for the catalytic oxidation of recalcitrant compounds.

The heterogenization of homogeneous catalysts develops and easy handling in different catalytic reactions [9, 10]. The study of metal complexation is increasing [11, 12], although among the variety of heterogenization techniques, the adsorption better supports ion species onto polymeric matrices. The efficiency of the oxidation reaction depends on the catalytic activity mostly disturbed by the leaching of the metal content [13]. Therefore, the selection of the adsorbent directs the effectiveness of the $\mathrm{Cu}(\mathrm{II})$ heterogenization.

The polymers attract special interest as supports because they have a rigid and crosslinked network where catalytic metals were attached [14], and where catalytic properties were preserved. The sorption onto materials of biological origin was recognized as an emerging technique [12, 15, 16]. Materials such as poly(4-vinylpyridine) (PVP) and poly(D-glucosamine) were selected as catalytic supports because of their pyridyl and amino radicals.

PVP with a structural formula presented in Figure 1a, is a very efficient adsorbent due to its pyridyl group has a strong affinity with metals. The three-dimensional and the long chain structure of PVP provides a molecule trap, which is beneficial to maintain the interaction between $\mathrm{Cu}(\mathrm{II})$ and polymeric surface [17]. For this reason, PVP was studied as a ligand of metals to form soluble homogeneous complexes $[18,19]$, although its adsorption capacity and catalytic activity as a heterogeneous catalyst is still unknown.

Normally, adsorption studies employ synthetic polymers but an important effort is being devoted to use biopolymers instead [20]. The biopolymer group includes materials such as starch derivatives, gelatin, cellulose, derivatives of chitin, and chitosan materials [21]. Chitosan (Figure 1b) is a partially acetylated glucosamine biopolymer resulting from the alkaline deacetylation of Chitin (poly $(N$-acetyl- $\beta$-D-glucosamine)), which is the second most abundant biopolymer in nature close to cellulose [20]. Chitosan actually is a heteropolymer containing both glucosamine and acetylglucosamine units. The presence of amine groups explains its affinity for metal ions. Based on a previous report [21], chitosan is a promising support due to its affinity with metals and its lack of diffusion problems when it was used as a catalyst. 
(a)<smiles>CCC(C)c1ccncc1</smiles>

(b)

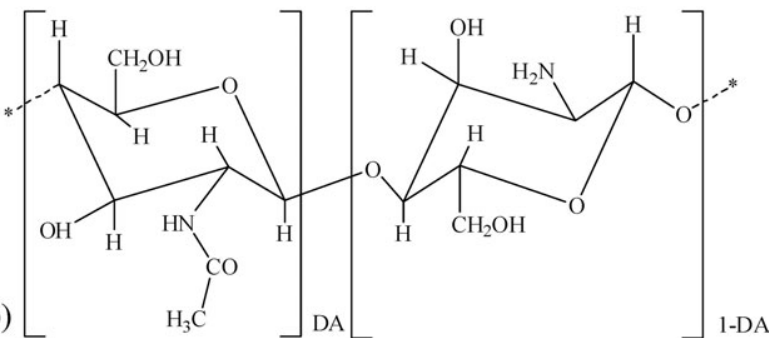

Figure 1. Structural formulas of (a) poly(4-vynilpyridine) structural formula and (b) poly(D-glucosamine).

The aim of this work is to perform and evaluate the heterogenization of homogeneous catalysts by the adsorption of $\mathrm{Cu}(\mathrm{II})$ over polymeric materials. For this purpose, the influence of variables such as the polymeric support, $\mathrm{pH}$, and temperature was evaluated in order to obtain a suitable catalyst capable to promote the wet oxidation of recalcitrant compounds without metal release.

\section{MATERIALS AND METHODS}

\section{Materials}

PVP 2\% crosslinked powder ( $\mathrm{PVP}_{2}$; Ref. 81391) and PVP $25 \%$ crosslinked beads ( PVP $_{25}$; Ref. 81393) were purchased from Sigma-Aldrich. As indicated in the technical sheet from Sigma-Aldrich, both PVP 2\% and 25\% are crosslinked with divinylbenzene. Chitosan beads were supplied by E. Guibal (Laboratoire de Génie de l'Environnement Industriel, Ecole des Mines d'Alès, France) and synthesized according to an original procedure [22]. Copper sulfate pent hydrated with $99 \%$ of purity $\left(\mathrm{CuSO}_{4} \cdot 5 \mathrm{H}_{2} \mathrm{O}\right.$ ) was obtained from SigmaAldrich, while hydrochloric acid $(\mathrm{HCl}) 2 \mathrm{~N}$ standard solution and sulfuric acid $\left(\mathrm{H}_{2} \mathrm{SO}_{4}\right) 99 \%$ were purchased from Fluka. Phenol 99\% and hydrogen peroxide $\left(\mathrm{H}_{2} \mathrm{O}_{2}\right) 30 \%(\mathrm{w} / \mathrm{v} ; 100$ vol.) PA were purchased from Panreac. Distilled water was used for all reagent solutions and employed as solvent.

\section{Methods}

The heterogenization of $\mathrm{Cu}(\mathrm{II})$ was performed by using a batch adsorption system, which consists of six beakers of 250 $\mathrm{mL}$ submerged in a thermostatic water bath, Figure 2. A mother solution with a high concentration of $1.0 \mathrm{~g} \mathrm{~L}^{-1}$ of $\mathrm{Cu}(\mathrm{II})$ was prepared by dissolving copper sulfate in distilled water. Six solutions with different $\mathrm{Cu}(\mathrm{II})$ concentrations (0.1, $0.2,0.4,0.6,0.8$, and $1.0 \mathrm{~g} \mathrm{~L}^{-1}$ ) of $0.2 \mathrm{~L}$ were prepared by diluting the mother solution in distilled water to the correct concentration. Every batch adsorption system was agitated with a magnetic stirrer $(90 \mathrm{rpm})$ for $5 \mathrm{~h}$ at 20,30 , and $40^{\circ} \mathrm{C}$. As the purpose of the research is to work at soft conditions, avoiding energy expenses, the use of the catalyst was made at mild conditions as well. It would be possible to use higher temperatures, as far as the polymer matrices will not be destroyed. The $\mathrm{pH}$ was measured twice, before the polymer was put in contact with the $\mathrm{Cu}(\mathrm{II})$ solutions and at the end of the adsorption period. The adsorption begin when $1 \mathrm{~g}$ of

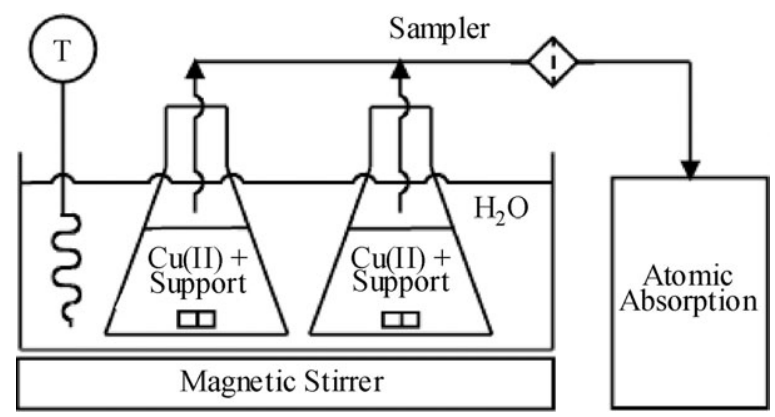

Figure 2. Batch adsorption set-up for the heterogenization of homogeneous catalysts.

the adsorbent was added into each of the six $\mathrm{Cu}(\mathrm{II})$ solutions. Samples of $0.1 \mathrm{~mL}$ were taken with a syringe and filtered ( $45 \mu \mathrm{m}$ pore membrane) at different time intervals to control the residual $\mathrm{Cu}(\mathrm{II})$ concentration in the supernatant. $\mathrm{Cu}(\mathrm{II})$ concentration was determined by analyzing the samples in an Atomic absorption spectrometer. After $5 \mathrm{~h}$, the polymer-Cu(II) material was recovered by filtration $(150 \mathrm{~nm}$ pore membrane), then cleaned with distilled water, dried at room temperature for $24 \mathrm{~h}$ and stored in a dry container.

\section{Catalytic Oxidation}

The catalytic oxidation of phenol was conducted at $30^{\circ} \mathrm{C}$ in a batch stirred tank reactor of $500 \mathrm{~mL}$ in volume at atmospheric pressure. The initial phenol concentration was $1 \mathrm{~g} \mathrm{~L}^{-1}$ and $\mathrm{H}_{2} \mathrm{O}_{2}$ was used as the oxidant at the stoichiometric phenol/peroxide $\left(\mathrm{Ph}: \mathrm{H}_{2} \mathrm{O}_{2}\right)$ molar ratio (1:14). The mass of the added catalyst was equivalent to $50 \mathrm{mg} \mathrm{L}^{-1}$ of $\mathrm{Cu}(\mathrm{II})$ in solution.

After the selection of the best catalyst, the process was performed at $\mathrm{pH} 6$ by using a buffer solution of $\mathrm{NaOH}$ and $\mathrm{K}_{2} \mathrm{HPO}_{4}$. Reaction progress was monitored by withdrawing 5 $\mathrm{mL}$ samples for $2 \mathrm{~h}$ of reaction, and then analyzed by HPLC and Atomic absorption to determine the remaining concentration of phenol and copper, respectively.

\section{Analytical Procedure}

The residual $\mathrm{Cu}$ (II) concentration in the supernatant was determined by an Atomic Absorption Spectrometer (Perkin Elmer, model 3110) (AA) with a specific lamp for the element of copper (Perkin Elmer, Ref. 01074). The samples were diluted in order to avoid saturation of the detector signal for the case of copper concentrations more than $10 \mathrm{mg} \cdot \mathrm{L}^{-1}$. The dilution of samples was made with a solution of $\mathrm{HCl} 1 \%$. The analyses were performed at $325 \mathrm{~nm}$ of wavelength [23]. The calibration curve was performed using various standards of known $\mathrm{Cu}(\mathrm{II})$ concentration.

Infrared spectroscopy was made using a Perkin-ElmerSpectrum spectrometer. The preparation of the samples was based on grinding the polymers until powder. Then, the powder was directly analyzed using a diamond cell.

\section{RESULTS AND DISCUSSION}

The adsorption capacity of $\mathrm{Cu}(\mathrm{II})$ is the basic variable to be considered on the evaluation of the heterogenization of $\mathrm{Cu}(\mathrm{II})$. The adsorption capacities $(q)$ of $\mathrm{Cu}(\mathrm{II})$ onto $\mathrm{PVP}_{2}$, $\mathrm{PVP}_{25}$, and chitosan were calculated by a mass balance where the initial $\left(C_{0}\right)$ and final $\left(C_{\mathrm{e}}\right)$ concentration $\left(\mathrm{g} \mathrm{L}^{-1}\right)$ of $\mathrm{Cu}(\mathrm{II})$, the volume $(V)$ of bulk solution $(\mathrm{mL})$, and the mass $(\mathrm{m})$ of the adsorbent $(\mathrm{g})$ were correlated by Eq. 1 : 


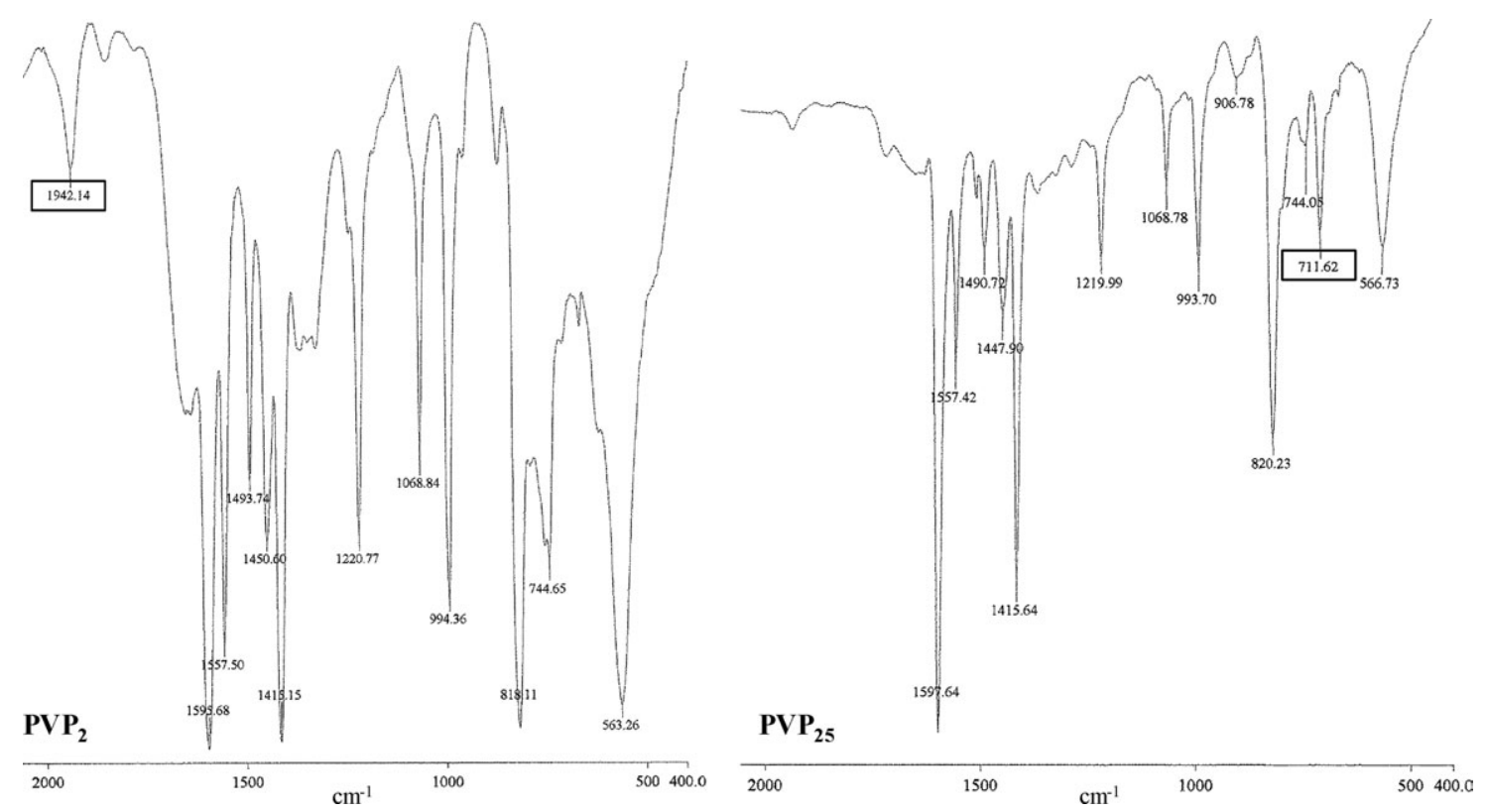

Figure 3. FTIR spectra between 2000 and $400 \mathrm{~cm}^{-1}$ of $\mathrm{PVP}_{2}$ and $\mathrm{PVP}_{25}$.

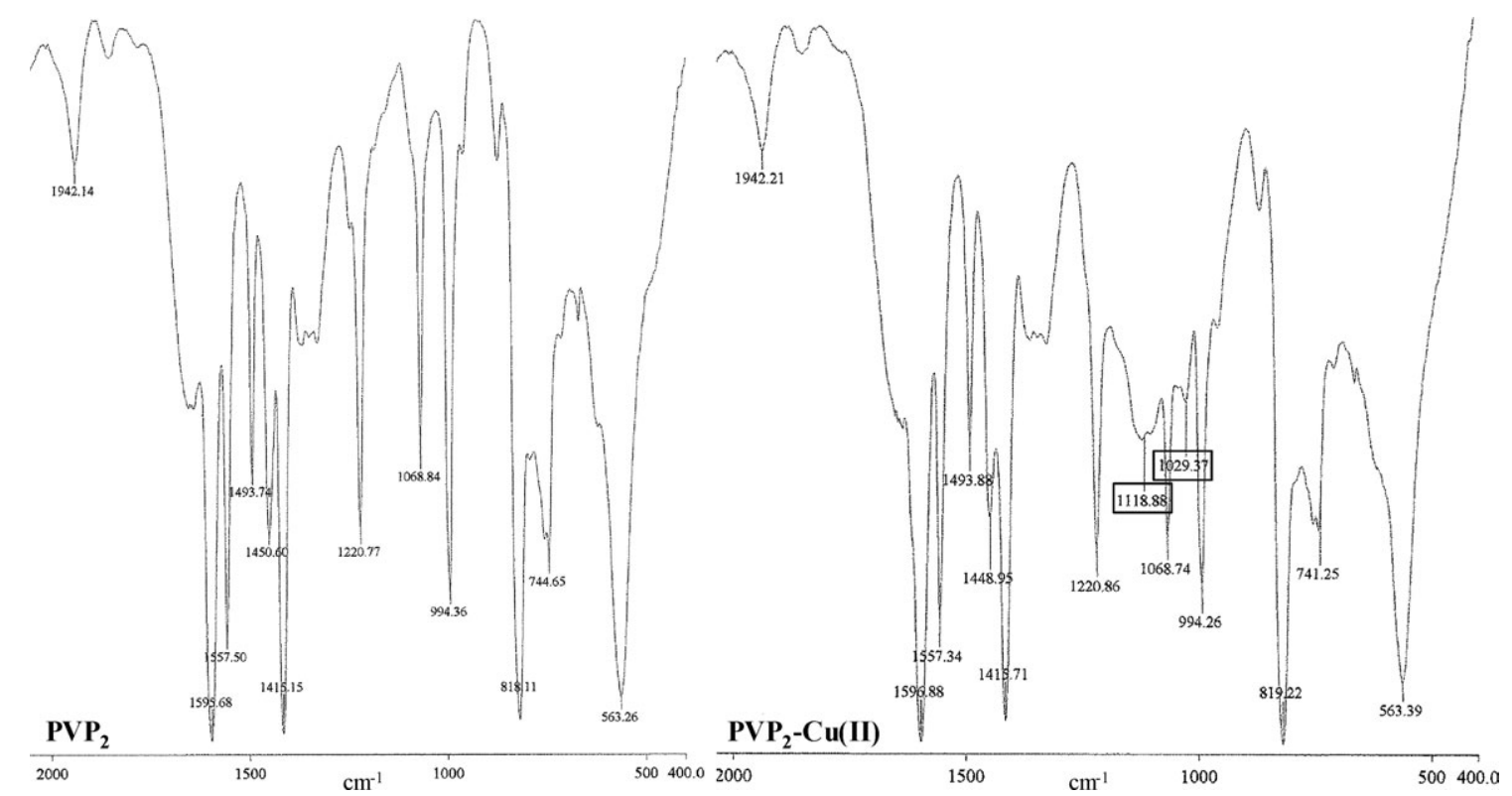

Figure 4. FTIR spectra between 2000 and $400 \mathrm{~cm}^{-1}$ of $\mathrm{PVP}_{2}$ and $\mathrm{PVP}_{2}$-Cu(II).

$q=\frac{C_{0}-C_{\mathrm{e}}}{m} \cdot V$

\section{Fourier Transform Infrared Spectroscopy (FTIR) Analysis}

The characterization of PVP-support by FTIR was made to detect the differences existing between $\mathrm{PVP}_{2}$ and $\mathrm{PVP}_{25}$. The Figure 3 presents the FTIR absorption spectrum of $\mathrm{PVP}_{2}$ and $\mathrm{PVP}_{25}$ against an arbitrary transmittance. From the differences of vibrations signals, $\mathrm{PVP}_{2}$ presented a vibration at $1942 \mathrm{~cm}^{-1}$, which reflects the presence of substituted double bonds on its matrix, confirming the substitution pattern of a benzene nucleus. For the case of $\mathrm{PVP}_{25}$, it appears a vibration at $711 \mathrm{~cm}^{-1}$ absorption band, which can be assigned to out-of-plane bending and describes the orientation of the aromatic rings with five adjacent hydrogen atoms, promoted by its $25 \%$ of crosslinking. These characteristics have been observed for metal loading purposes [24, 25].

In Figure 4 , it is presented the FTIR spectra of $\mathrm{PVP}_{2}$ and the catalyst $\left(\mathrm{PVP}_{2}-\mathrm{Cu}(\mathrm{II})\right)$. It can be observed two characteristic vibration signals at 1029 and $1118 \mathrm{~cm}^{-1}$. Vibration at 1029 $\mathrm{cm}^{-1}$ band was assigned to the $\mathrm{Cu}(\mathrm{II})$ presence on the matrix that causes some changes on the pyridine ring orientation [25]. Absorption band at $1118 \mathrm{~cm}^{-1}$ was assigned to the stretching and bending of $\mathrm{S}-\mathrm{O}$ vibration of $\mathrm{SO}_{4}^{-2}$ [25]. FTIR spectra of $\mathrm{PVP}_{25}$ and $\mathrm{PVP}_{25}$-Cu(II) were also evaluated and the presence of $\mathrm{Cu}(\mathrm{II})$ and $\mathrm{SO}_{4}^{-2}$ is evident at the same vibration bands as for $\mathrm{PVP}_{2}-\mathrm{Cu}(\mathrm{II})$. 


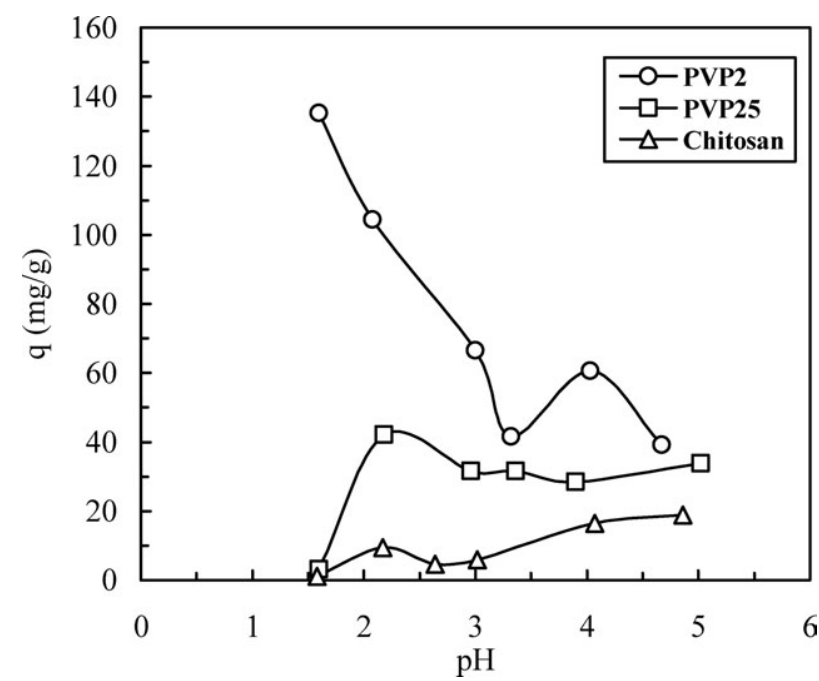

Figure 5. Adsorption capacity of $\mathrm{Cu}(\mathrm{II})$ onto $\mathrm{PVP}_{2}, \mathrm{PVP}_{25}$, and chitosan. $[\mathrm{Cu}(\mathrm{II})]_{0}=0.1-1.0 \mathrm{~g} \mathrm{~L}^{-1}$ for PVPs and $[\mathrm{Cu}(\mathrm{II})]_{0}$ $=0.01-0.10 \mathrm{~g} \mathrm{~L}^{-1}$ for chitosan, $m=1 \mathrm{~g}, T=30^{\circ} \mathrm{C}$, as a function of $\mathrm{pH}$.

From the above, differences between $\mathrm{PVP}_{2}$ and $\mathrm{PVP}_{25}$ do not seem important for the adsorption of $\mathrm{Cu}(\mathrm{II})$; therefore, it is essential to evaluate the influence of variables such as temperature, $\mathrm{pH}$, or initial $\mathrm{Cu}(\mathrm{II})$ concentrations.

\section{Effect of the pH on the Heterogenization}

During the adsorption of $\mathrm{Cu}(\mathrm{II})$, the $\mathrm{pH}$ values of the solution at equilibrium changed from $\mathrm{pH} 5.0$ to 5.5 , values that describe a stable $\mathrm{pH}$ system. The small $\mathrm{pH}$ change describes the competition of $\mathrm{Cu}(\mathrm{II})$ and $\mathrm{H}_{3} \mathrm{O}^{+}$for binding to available sites in the polymer surface [15]. The behavior of each support at different $\mathrm{pH}$ is important because the catalyst (Cu(II)support) was planned to interact in a variable $\mathrm{pH}$ media, such as the oxidation. Figure 5 shows the adsorption capacities of $\mathrm{PVP}_{2}, \mathrm{PVP}_{25}$, and chitosan as a function of the $\mathrm{pH}$. Sulfuric acid was used to adjust the $\mathrm{pH}$ of $\mathrm{Cu}(\mathrm{II})$ solutions. The removal of $\mathrm{Cu}(\mathrm{II})$ at $20^{\circ} \mathrm{C}$ was evaluated at $\mathrm{pH}<5$ because of the distribution of $\mathrm{Cu}(\mathrm{II})$ species (Figure 6). Copper precipitation appears as hydroxide at values above $\mathrm{pH} 5$ with the initial $\mathrm{Cu}(\mathrm{II})$ concentration of $1 \mathrm{~g} \mathrm{~L}^{-1}(15.7 \mathrm{mM})$. Results show that $\mathrm{Cu}(\mathrm{II})$ adsorption presents different behavior depending on each adsorbent. For the case of $\mathrm{PVP}_{2}$, the adsorption capacity declines when $\mathrm{pH}$ was increased, presenting better results on acid media, up to $140 \mathrm{mg} \mathrm{g}^{-1}$. $\mathrm{PVP}_{25}$ presents values around $40 \mathrm{mg} \mathrm{g}^{-1}$ between $\mathrm{pH} 2$ to 5 , but at $\mathrm{pH}<2$ the adsorption capacity was negligible because the acid media with high content of $\mathrm{H}_{3} \mathrm{O}^{+}$ions compete with $\mathrm{Cu}(\mathrm{II})$ for the formation of bonds with available radicals of $\mathrm{PVP}_{25}$. However, chitosan presented better results at $\mathrm{pH} 5$ (20 $\mathrm{mg} \mathrm{g}^{-1}$ ) where $\mathrm{Cu}(\mathrm{II})$ removal was more effective than at $\mathrm{pH}$ 2. Overall, it is evident that $\mathrm{pH}$ influences the heterogenization of $\mathrm{Cu}(\mathrm{II})$, even more the diversity of behaviors at different $\mathrm{pH}$ shows that the structural differences (crosslinking or active radicals) of $\mathrm{PVP}_{2}, \mathrm{PVP}_{25}$, and chitosan have high influence on the heterogenization. $\mathrm{PVP}_{2}$ was the best material for the heterogenization of $\mathrm{Cu}(\mathrm{II})$ in acid media, it experienced a partial destruction and it was suggested a better exposure of pyridyl radicals. $\mathrm{PVP}_{25}$ is suitable at variable $\mathrm{pH}$, indicating that its structure was stronger than $\mathrm{PVP}_{2}$ in acid media, similarly reported elsewhere [26]. Chitosan is more efficient near $\mathrm{pH} 5$ due to its cationic adsorption increases at basic $\mathrm{pH}$ media as expected [27]. Finally, it was decided to develop the

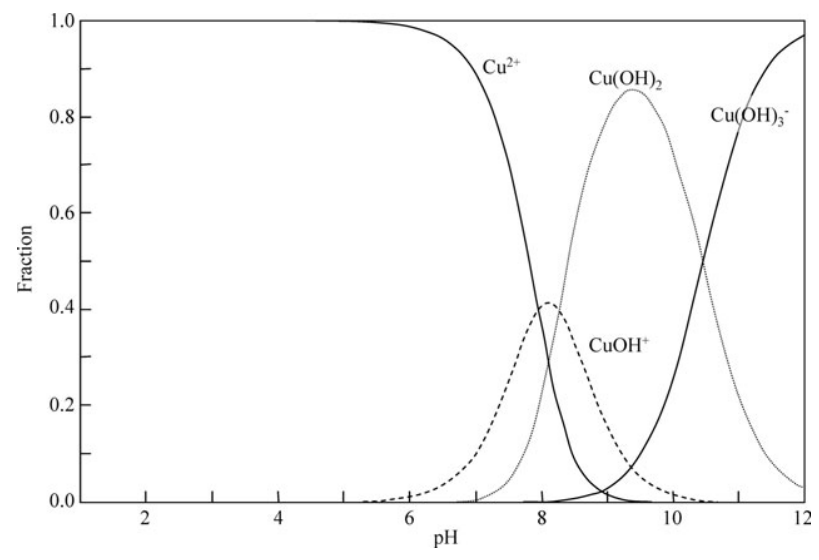

Figure 6. Distribution of $\mathrm{Cu}(\mathrm{II})$ species as a function of $\mathrm{pH}$.

Table 1. Physical properties of polymers PVPs and chitosan.

\begin{tabular}{|c|c|c|c|c|}
\hline Support & $\begin{array}{l}\text { Particle } \\
\text { size } \\
(\mathrm{mm})\end{array}$ & $\begin{array}{c}\text { Area } \\
\text { BET } \\
\left(\mathbf{m}^{2} \mathbf{g}^{-1}\right)\end{array}$ & $\begin{array}{l}\text { Average } \\
\text { pore } \\
\text { diameter } \\
\text { (nm) }\end{array}$ & $\begin{array}{c}\text { Adsorption } \\
\text { capacity } \\
\left(\mathbf{m g} \mathbf{g}^{-1}\right)\end{array}$ \\
\hline $\mathrm{PVP}_{2}$ & $\sim 0.25$ & 0.57 & 7.50 & \\
\hline $\mathrm{PVP}_{2}-\mathrm{Cu}(\mathrm{II})$ & & 1.73 & 18.82 & 71 \\
\hline $\mathrm{PVP}_{25}$ & $\sim 0.85$ & 12.16 & 17.70 & \\
\hline $\mathrm{PVP}_{25}-\mathrm{Cu}(\mathrm{II})$ & & 18.75 & 21.64 & 48 \\
\hline Chitosan* & $\sim 2.50$ & - & - & \\
\hline Chitosan-Cu(II)* & & - & - & 10 \\
\hline
\end{tabular}

*Difficult to be analyzed by standard methods because of its physical state of gel bead.

heterogenization of $\mathrm{Cu}(\mathrm{II})$ at $\mathrm{pH} 5$ because, without $\mathrm{pH}$ control, the adsorption process does not present $\mathrm{pH}$ instability and because the catalyst was used at $\mathrm{pH} 6$.

\section{Effect of the Adsorbent on the Heterogenization}

The uptake of $\mathrm{Cu}(\mathrm{II})$ was periodically evaluated, the initial copper concentration in solution was $1.0 \mathrm{~g} \mathrm{~L}^{-1}$ for $\mathrm{PVP}_{2}$ and $\mathrm{PVP}_{25}$, for chitosan was $0.1 \mathrm{~g} \mathrm{~L}^{-1}$ because initial experimental attempt demonstrated that chitosan presents low adsorption capacities. The experiments were carried out at the initial $\mathrm{pH} 5$ and at the temperature of $20^{\circ} \mathrm{C}$. The $\mathrm{Cu}(\mathrm{II})$ concentration in solution was monitored for $5 \mathrm{~h}$, considering that all the adsorbent materials presented quite rapid adsorption rates at the first $2 \mathrm{~h}$ where equilibrium was reached, then adsorption contact time of $5 \mathrm{~h}$ was used for all further experiments. For instance, studies with chitosan have reported immediate adsorption uptake after $1 \mathrm{~h}$ [28].

From Table 1, it is evident the differences between the adsorption capacities of each support. Comparison between $\mathrm{PVP}_{2}$ and $\mathrm{PVP}_{25}$ showed that heterogenization of $\mathrm{Cu}(\mathrm{II})$ into materials with higher crosslinking had less adsorption capacities than their homologous with low crosslinking, even if they have higher BET area. Therefore, diversity of results was partially caused by the particle size of each material, because it was reported that adsorption capacity of materials with small particle size (e.g., $\mathrm{PVP}_{2}$ ) were higher compared with beads [29]. For instance, beads (e.g., $\mathrm{PVP}_{25}$ or chitosan) experiment obstruction problems in their contact area due to crosslinkage. A previous work described lower adsorption 
capacity while the crosslinking increases [30]. Actually, the interaction between $\mathrm{Cu}$ and polymer is an important characteristic because while chitosan has $-\mathrm{NH}_{2}$ radicals, PVPs have pyridyl radicals. Pyridyl group proved to be favorable for the adsorption of copper ions as this study shows [30]. Therefore, chitosan does not just present less adsorption capacities than the rest of polymers because of the external configuration (particle size) but also because of its amino radicals.

\section{Effect of the Temperature on the Heterogenization}

To study the influence of temperature over the heterogenization of the $\mathrm{Cu}(\mathrm{II})$ onto polymeric materials, it was schemed the adsorption capacity against the equilibrium concentrations of $\mathrm{Cu}(\mathrm{II})$ ions in solution at three different temperatures $\left(20,30\right.$, and $\left.40^{\circ} \mathrm{C}\right)$.

Figure $7 \mathrm{a}$ shows the evolution of $\mathrm{PVP}_{2}$ adsorption capacity $(q)$ when temperature varies. $\mathrm{PVP}_{2}$ with $2 \%$ of crosslinker presents high percent of ordered active radicals over its exposed area, but results show better $q$ results with $\mathrm{PVP}_{25}$ at $20^{\circ} \mathrm{C}$ (Figure $7 \mathrm{~b}$ ). $\mathrm{PVP}_{2}$ shows saturation at $20^{\circ} \mathrm{C}$ but it seems to expose more amino radicals at 30 and $40^{\circ} \mathrm{C}$. Then, the $q$ of $\mathrm{PVP}_{2}$ at $40^{\circ} \mathrm{C}\left(90 \mathrm{mg} \mathrm{g}^{-1}\right)$ and $30^{\circ} \mathrm{C}\left(71 \mathrm{mg} \mathrm{g}^{-1}\right)$ represent the equilibrium of an unsaturated material compared with the values obtained at $20^{\circ} \mathrm{C}\left(39 \mathrm{mg} \mathrm{g}^{-1}\right)$.

From $\mathrm{PVP}_{25}$ (Figure $7 \mathrm{~b}$ ), it was deduced that $\mathrm{PVP}_{25}$ performs a higher adsorption capacity than $\mathrm{PVP}_{2}$ and chitosan at $20^{\circ} \mathrm{C}$ despite of its $25 \%$ of crosslinker. The adsorption capacity of $\mathrm{PVP}_{25}$ decreases as effect of the temperature increment; for instance, there was no better adsorption activity at temperatures more than $40^{\circ} \mathrm{C}$. Obviously, $q$ was low because temperature increased the Cu(II) ions excitement, then the adsorption was hardly performed due to the attraction of $\mathrm{Cu}(\mathrm{II})$ to the polymeric surface is lower.

Previous reports have worked with chitosan in powder and flakes, from where it was obtained the highest $q$ with powder materials at three tested temperatures [15, 29]. In Figure 7c, chitosan adsorption capacities kept constant even when temperature changed, characterizing chitosan as a polymer capable to attract the same amount of $\mathrm{Cu}(\mathrm{II})$ ions between 20 and $40^{\circ} \mathrm{C}$. It was suggested that temperature could have more influence over Cu(II)-chitosan interaction if its adsorption capacities were higher.

Finally, given temperature has high influence over $\mathrm{PVP}_{2}$ and $\mathrm{PVP}_{25}$ adsorption capacities while had no effect on chitosan. It was confirmed that the exposed surface, which was formed by energy sites of available radicals, changed when temperature increased. Finally, it was established that temperature change has high influence on the heterogenization of copper [15].

\section{Equilibrium Studies over the Heterogenization}

\section{Langmuir Study}

The equilibrium data were analyzed by known adsorption isotherm models, which provided the basic theory in adsorption behavior. The Langmuir theory of 1916 [31], which follow the idea of a monolayer surface adsorption onto an ideal surface and was expressed by Eq. 2 :

$q=\frac{q_{\mathrm{max}} \cdot K \cdot C_{\mathrm{e}}}{1+K \cdot C_{\mathrm{e}}}$

where the adsorption capacity $q\left(\mathrm{mg} \mathrm{g}^{-1}\right)$ is a function of $\mathrm{Cu}(\mathrm{II})$ concentration at the equilibrium $C_{\mathrm{e}}\left(\mathrm{mg} \mathrm{L}^{-1}\right)$, the Langmuir equilibrium constant $K\left(\mathrm{~L} \mathrm{mg}^{-1}\right)$ and the maximum adsorption capacity $q_{\max }\left(\mathrm{mg} \mathrm{g}^{-1}\right)$. So that, linearization of Eq. 2 gives Eq. 3:

$\frac{C_{\mathrm{e}}}{q}=\frac{C_{\mathrm{e}}}{q_{\max }}+\frac{1}{K \cdot q_{\max }}$
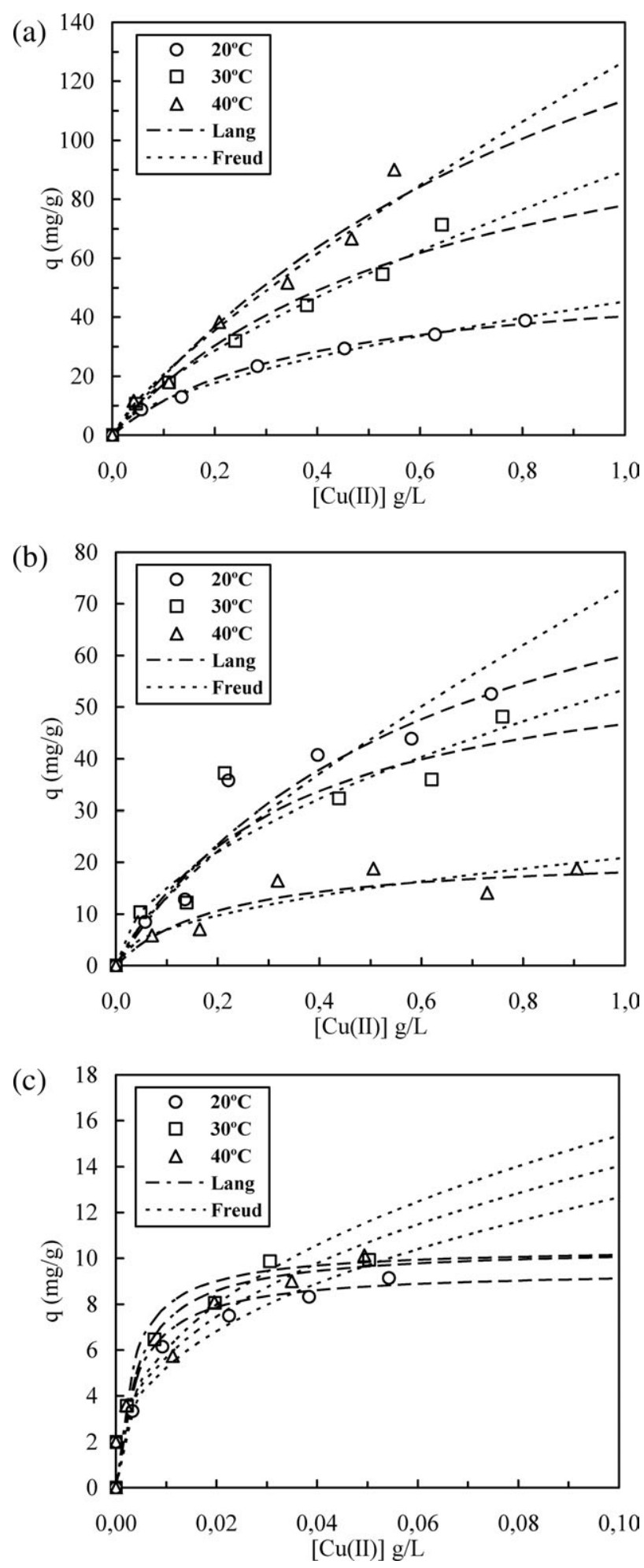

Figure 7. Adsorption isotherms of $\mathrm{Cu}$ (II) onto (a) $\mathrm{PVP}_{2}$, (b) $\mathrm{PVP}_{25}$, and (c) chitosan with their respective Langmuir and Freundlich evaluation at 20,30 , and $40^{\circ} \mathrm{C}$. $[\mathrm{Cu}(\mathrm{II})]_{0}=0.1-1.0 \mathrm{~g} \mathrm{~L}^{-1}$ for (a) and (b), $[\mathrm{Cu}(\mathrm{II})]_{0}=$ $0.01-0.10 \mathrm{~g} \mathrm{~L}^{-1}$ for (c), $m=1 \mathrm{~g}$.

Langmuir constant $K$ and $q_{\max }$ were calculated from the plot of $C_{\mathrm{e}} / q$ vs. $C_{\mathrm{e}}$. Then, on Table 2 Langmuir parameters were listed ( $K$ and $q_{\max }$ ) as indicators of the adsorption process. $K$ represents the equilibrium constant and $q_{\max }$ 
Table 2. Langmuir parameters of $\mathrm{Cu}(\mathrm{II})$ adsorption onto $\mathrm{PVP}_{2}, \mathrm{PVP}_{25}$, and chitosan, $m=1 \mathrm{~g}$ at 20,30 , and $40^{\circ} \mathrm{C}$.

\begin{tabular}{|c|c|c|c|c|}
\hline Support & $\begin{array}{c}\text { Temperature } \\
\left({ }^{\circ} \mathrm{C}\right)\end{array}$ & $\begin{array}{c}K \\
\left(\mathrm{~L} \mathrm{mg}^{-1}\right)\end{array}$ & $\underset{\left(m g g^{-1}\right)}{q_{\max }}$ & $\boldsymbol{R}^{2}$ \\
\hline \multirow[t]{3}{*}{$\mathrm{PVP}_{2}$ (powder) } & 20 & $2.6 \times 10^{-3}$ & 56 & 0.9724 \\
\hline & 30 & $1.5 \times 10^{-3}$ & 128 & 0.8356 \\
\hline & 40 & $0.9 \times 10^{-3}$ & 238 & 0.4853 \\
\hline \multirow{3}{*}{$\mathrm{PVP}_{25}$ (beads) } & 20 & $1.6 \times 10^{-3}$ & 98 & 0.7029 \\
\hline & 30 & $2.9 \times 10^{-3}$ & 63 & 0.7478 \\
\hline & 40 & $4.7 \times 10^{-3}$ & 22 & 0.8596 \\
\hline \multirow[t]{3}{*}{ Chitosan (beads) } & 20 & $2.4 \times 10^{-1}$ & 10 & 0.9867 \\
\hline & 30 & $3.1 \times 10^{-1}$ & 11 & 0.9880 \\
\hline & 40 & $2.2 \times 10^{-1}$ & 11 & 0.9715 \\
\hline
\end{tabular}

expresses the maximum adsorption capacity at monolayer levels [32].

$\mathrm{PVP}_{2}$ case shows that $K$ constant decreases when temperature increases, indicating the lack of saturation onto the sorbent surface at high temperatures and characterizing $\mathrm{PVP}_{2}$ as a material with high adsorption capacities at high temperatures. For instance the highest $q_{\max }$ value was obtained at $40^{\circ} \mathrm{C}$ where $\mathrm{Cu}(\mathrm{II})$ ions were well spread in the sorbet media, then the temperature facilitates the interaction of $\mathrm{PVP}_{2}$ surface and $\mathrm{Cu}(\mathrm{II})$ ions.

Langmuir constants for $\mathrm{PVP}_{25}$ (Table 2) show that $K$ values increase with temperature and it describes high equilibrium constants at 30 and $40^{\circ} \mathrm{C}$. It was observed a negative temperature effect over $\mathrm{PVP}_{25}$ surface (reduction of adsorption capacity), that is the equilibrium constant increases because $\mathrm{Cu}(\mathrm{II})$ ions have difficulties to form bonds with the polymeric surface. Therefore $\mathrm{PVP}_{25}$ has low $q_{\max }$ values at high temperatures, which describes difficulties to form $\mathrm{Cu}(\mathrm{II})$-polymer bonds at $40^{\circ} \mathrm{C}$.

Likewise, chitosan Langmuir constants were presented on Table 2. $K$ constant remains unchangeable at different temperatures. This behavior describes chitosan as a polymer capable to obtain equivalent adsorption capacities at different temperatures; in consequence, $q_{\max }$ did not change at any tested temperature.

After Langmuir evaluation, $\mathrm{PVP}_{2}$ presented the best energetic properties at monolayer coverage when compared with $\mathrm{PVP}_{25}$ and chitosan, at this temperature range. Moreover, data were also evaluated by Freundlich model as follows.

\section{Freundlich Study}

Experimental data were analyzed by the Freundlich model [33], which assumes a heterogeneous surface with unequal adsorption sites and was expressed by Eq. 4 as a function of two constants called Freundlich $K_{\mathrm{f}}$ and $1 / n$ parameters respectively:

$q=K_{\mathrm{f}} \cdot\left(C_{\mathrm{e}}\right)^{1 / n}$

where $K_{\mathrm{f}}\left(\mathrm{mg} \mathrm{g}^{-1}\right)$ indicates the Freundlich adsorption coefficient of the polymer and $1 / n\left(\mathrm{~L} \mathrm{~g}^{-1}\right)$ represents the adsorption intensity of formed bonds. For instance, $n$ values between 1 and 10 range, it can be stated that the adsorption is favorable. The linearization of Eq. 4 gives Eq. 5 :

$\operatorname{Ln}(q)=\operatorname{Ln}\left(K_{\mathrm{f}}\right)+\frac{1}{n} \cdot \operatorname{Ln}\left(C_{\mathrm{e}}\right)$

After plotting Eq. 5, Freundlich constants were obtained and the results presented in Table 3 . For $\mathrm{PVP}_{2}$ case, $K_{\mathrm{f}}$ constant decreases with temperature; this effect shows less absorbance affinity when temperature increased. Additionally,
Table 3. Freundlich parameters of $\mathrm{Cu}(\mathrm{II})$ adsorption onto $\mathrm{PVP}_{2}, \mathrm{PVP}_{25}$, and chitosan, $m=1 \mathrm{~g}$ at 20,30 , and $40^{\circ} \mathrm{C}$.

\begin{tabular}{lcccc}
\hline Support & $\begin{array}{c}\text { Temperature } \\
\left({ }^{\circ} \mathbf{C}\right)\end{array}$ & $\begin{array}{c}\mathbf{1} / \boldsymbol{n} \\
\left(\mathbf{L ~} \mathbf{g}^{-\mathbf{1}}\right)\end{array}$ & $\begin{array}{c}\boldsymbol{K}_{\mathbf{f}} \\
\left(\mathbf{m g ~ g}^{-\mathbf{1}}\right)\end{array}$ & $\boldsymbol{R}^{\mathbf{2}}$ \\
\hline PVP $_{2}$ (powder) & 20 & 0.58 & 0.80 & 0.9914 \\
& 30 & 0.71 & 0.67 & 0.9943 \\
& 40 & 0.79 & 0.54 & 0.9727 \\
PVP $_{25}$ (beads) & 20 & 0.74 & 0.43 & 0.9059 \\
& 30 & 0.55 & 1.18 & 0.8001 \\
& 40 & 0.48 & 0.78 & 0.8055 \\
Chitosan (beads) & 20 & 0.38 & 2.16 & 0.9688 \\
& 30 & 0.41 & 2.36 & 0.9540 \\
& 40 & 0.39 & 2.30 & 0.9702 \\
\hline
\end{tabular}

$1 / n$ small values describe the strength of $\mathrm{Cu}(\mathrm{II})$-polymer bonds, which in this case, increases with temperature, showing that the bond strength is weaker at high temperatures. Overall, $\mathrm{PVP}_{2}$ presents better adsorption capacities at $40^{\circ} \mathrm{C}$ but at the same time its $\mathrm{Cu}(\mathrm{II})$-polymer bonds lose strength.

Freundlich $K_{\mathrm{f}}$ parameter for $\mathrm{PVP}_{25}$ does not present a tendency. $K_{\mathrm{f}}$ is nearly similar at 20 and $40^{\circ} \mathrm{C}$, while $K_{\mathrm{f}}$ is almost the double than the previous temperatures at $30^{\circ} \mathrm{C}$, this lack of tendency at different temperatures describes $\mathrm{PVP}_{25}$ as an unsteady energetic surface. Moreover, the decrease of $1 / n$ parameter represents the formation of stronger bonds, so that it was assumed that $\mathrm{PVP}_{25}$ has stronger $\mathrm{Cu}(\mathrm{II})$-polymer bonds when temperature increases.

From the evaluation of chitosan $K_{\mathrm{f}}$ and $1 / n$ parameters, it was seen that these parameters are almost nonsensible respect to temperature such as the previous Langmuir evaluation. Moreover, chitosan data show the formation of strong bonds with the possibility to have better adsorption coefficients than PVP polymers.

Figures $7 \mathrm{a}$ and $7 \mathrm{~b}$ plots Langmuir and Freundlich models for $\mathrm{PVP}_{2}$ and $\mathrm{PVP}_{25}$, respectively, the comparison between models showed that experimental data fitted either with Langmuir or Freundlich models. It was suggested that $\mathrm{PVP}_{2}$ and $\mathrm{PVP}_{25}$ have a homogeneous adsorption activity with an energetically heterogeneous surface. Figure $7 \mathrm{c}$ shows that Langmuir tendencies fitted well with the experimental data, describing chitosan as a support with a homogenous adsorption surface. This effect implies a well distribution of superficial energies, even when temperature increases.

\section{Thermodynamic Study}

Thermodynamic parameters describe the effect of temperature on $\mathrm{Cu}(\mathrm{II})$ heterogenization and evaluate the nature of the adsorption process. The thermodynamic constants, Gibbs free energy variation $\Delta G^{0}\left(\mathrm{~kJ} \mathrm{~mol}^{-1}\right)$, enthalpy variation $\Delta H^{0}$ $\left(\mathrm{kJ} \mathrm{mol}{ }^{-1}\right)$ and entropy variation $\Delta S^{0}\left(\mathrm{~kJ} \cdot \mathrm{mol}^{-1} \cdot \mathrm{K}\right)$ were calculated. The Gibbs free energy change of adsorption was defined by Eq. 6:

$\Delta G^{0}=-R T \cdot \operatorname{Ln}(K)$

where $K\left(\mathrm{~L} \mathrm{~mol}{ }^{-1}\right)$ was taken from the evaluation of the Langmuir model and $R$ is the Universal gas constant $(8.314 \mathrm{~J}$ $\mathrm{mol}^{-1} \mathrm{~K}^{-1}$ ). The $\Delta G^{0}$ values (Eq. 6) were listed in Table 4. The $\Delta G^{0}$ negative values describe spontaneous adsorption processes for the four of the polymeric supports. Literature determines that $\Delta G^{0}$ range from -8 to $-6 \mathrm{~kJ} \mathrm{~mol}^{-1}$ represents the bonding energy for an ion-exchange mechanism [34].

Note, for $\mathrm{PVP}_{2}$, the increment of $\Delta G^{0}$ implies less adsorption at high temperatures that is agreed with $K$ Langmuir constant, which presented less bond affinity. Hence, $\mathrm{PVP}_{2}$ adsorption capacity suggests a physical adsorption with a 
Table 4. Thermodynamic sorption parameters of $\mathrm{Cu}(\mathrm{II})$ removal onto $\mathrm{PVP}_{2}, \mathrm{PVP}_{25}$, and chitosan, $m=1 \mathrm{~g}$, at 20,30 , and $40^{\circ} \mathrm{C}$.

\begin{tabular}{|c|c|c|c|c|c|}
\hline Support & $T$ & $\begin{array}{c}K \\
\left(\mathrm{~L} \mathbf{~ m g}^{-1}\right)\end{array}$ & $\begin{array}{c}\Delta G^{0} \\
\left(\mathbf{k J ~} \mathrm{mol}^{-1}\right)\end{array}$ & 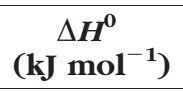 & $\begin{array}{c}\Delta s^{0} \\
\left(\mathrm{~kJ} \mathrm{~mol} \mathrm{~mol}^{-1} \mathrm{~K}^{-1}\right)\end{array}$ \\
\hline \multirow[t]{3}{*}{$\mathrm{PVP}_{2}$ (powder) } & $20^{\circ} \mathrm{C}$ & $2.6 \times 10^{-3}$ & -12.4 & -40.5 & -0.10 \\
\hline & $30^{\circ} \mathrm{C}$ & $1.5 \times 10^{-3}$ & -11.5 & & \\
\hline & $40^{\circ} \mathrm{C}$ & $0.9 \times 10^{-3}$ & -10.5 & & \\
\hline \multirow[t]{3}{*}{$\mathrm{PVP}_{25}$ (beads) } & $20^{\circ} \mathrm{C}$ & $1.6 \times 10^{-3}$ & -11.3 & 41.1 & 0.18 \\
\hline & $30^{\circ} \mathrm{C}$ & $2.9 \times 10^{-3}$ & -13.1 & & \\
\hline & $40^{\circ} \mathrm{C}$ & $4.7 \times 10^{-3}$ & -14.8 & & \\
\hline \multirow[t]{3}{*}{ Chitosan (beads) } & $20^{\circ} \mathrm{C}$ & $2.4 \times 10^{-1}$ & -23.5 & -3.1 & -0.10 \\
\hline & $30^{\circ} \mathrm{C}$ & $3.1 \times 10^{-1}$ & -24.9 & & \\
\hline & $40^{\circ} \mathrm{C}$ & $2.2 \times 10^{-1}$ & -24.9 & & \\
\hline
\end{tabular}

high desorption possibility. The $\Delta G^{0}$ range (from -12.4 to $-10.5 \mathrm{~kJ} \mathrm{~mol}^{-1}$ ) indicates that $\mathrm{PVP}_{2}-\mathrm{Cu}(\mathrm{II})$ bond was formed by electrostatic interactions between adsorption sites and $\mathrm{Cu}(\mathrm{II})$ ions, also called physical adsorption.

The $\Delta G^{0}$ for $\mathrm{PVP}_{25}$ shows an opposite behavior compared with $\mathrm{PVP}_{2}$, it decreases with temperature increment. $\Delta G^{0}$ values for $\mathrm{PVP}_{25}$ are lower than $\mathrm{PVP}_{2}$, but they suggest a feasible adsorption process promoted by low temperatures. The $\Delta G^{0}$ range from -14.8 to $-11.3 \mathrm{~kJ} \mathrm{~mol}^{-1}$, near to $-16 \mathrm{~kJ}$ $\mathrm{mol}^{-1}$, describes the adsorption as a charge transference from the adsorbent surface to $\mathrm{Cu}(\mathrm{II})$ ions to form a coordinate bond such as previous experiences [35].

Heterogenization over chitosan did not vary with temperature. The $\Delta G^{0}$ range from -24.9 to $-23.5 \mathrm{~kJ} \mathrm{~mol}^{-1}$ indicates that the ion exchange did not play a significant role in the adsorption process. Moreover, the interaction $\mathrm{Cu}(\mathrm{II})$-chitosan involves a charge sharing from chitosan active radicals to $\mathrm{Cu}(\mathrm{II})$ ions. Additionally, thermodynamic potentials such as enthalpy $\Delta H^{0}$ and entropy $\Delta S^{0}$ variations were determined by Eq. 7 and evaluated.

$\frac{d(\ln K)}{d T}=\frac{\Delta H^{0}}{R \cdot T^{2}}$

Equation 8 was obtained and $\Delta H^{0}$ results categorize the adsorption as endothermic or exothermic heterogenization process and Eq. 9

$\operatorname{Ln}(K)=-\frac{\Delta H^{0}}{R \cdot T}+\frac{\Delta S^{0}}{R}=-\frac{\Delta G^{0}}{R \cdot T}$

$\Delta G^{0}=\Delta H^{0}-T \Delta S^{0}$

$\Delta H^{0}$ and $\Delta S^{0}$ parameters were taken from the Van't Hoff plots Eq. 9 showed on Figure 8, where $\Delta H^{0}$ is the slope and $\Delta S^{0}$ is the intercept (Eq. 9). The thermodynamic behavior of $\mathrm{PVP}_{2}$ tends to decrease when temperature increases. Then, the adsorption capacity of $\mathrm{PVP}_{2}$ is exothermic $\left(-40.45 \mathrm{~kJ} \mathrm{~mol}^{-1}\right)$, also known as favorable heterogenization. However, $\mathrm{PVP}_{25}$ presents an endothermic behavior, probably caused by the temperature increment [36]. The thermodynamic behavior of chitosan presents no changes either exothermic or endothermic at temperature variation. Then, chitosan has a constant adsorption activity at different temperatures.

Thermodynamically, the best adsorption system was based on high negative $\Delta H^{0}$ values and high positive $\Delta S^{0}$ values. But, in fact, the free energy must decrease to have a spontaneous adsorption and the variation of entropy should be negative to suggest a decreasing in the randomness at the solid/solution interface during the adsorption of $\mathrm{Cu}(\mathrm{II})$. Nevertheless, these standards were not always followed, for

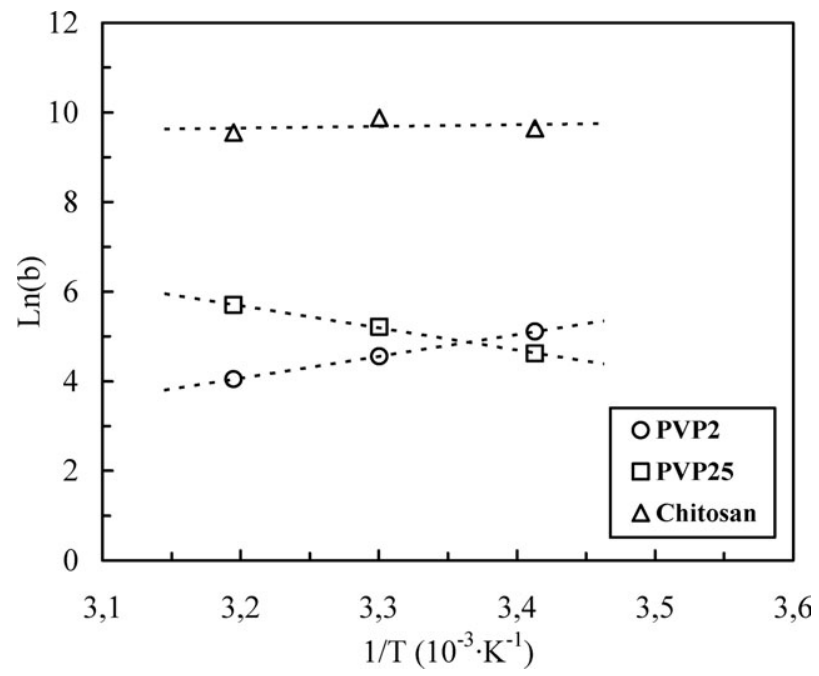

Figure 8. Van't Hoff diagram. Ln(b) versus $T^{-1}$. Thermodynamic tendencies of $\mathrm{PVP}_{2}, \mathrm{PVP}_{25}$, and chitosan. $[\mathrm{Cu}(\mathrm{II})]_{0}=$ $0.1-1.0 \mathrm{~g} \mathrm{~L}^{-1}$ for $\mathrm{PVP}_{2}$ and $\mathrm{PVP}_{25},[\mathrm{Cu}(\mathrm{II})]_{0}=0.01-0.10 \mathrm{~g} \mathrm{~L}^{-1}$ for chitosan, $m=1 \mathrm{~g}, T=20,30$, and $40^{\circ} \mathrm{C}$.

instance it was reported that adsorption capacity for $\mathrm{Cu}(\mathrm{II})$ onto sand increased when temperature decreased [37], and studies of organic compounds adsorbed onto activated carbon also reported endothermic adsorption [36]. At the end, the $\Delta S^{0}$ analysis describes the randomness degree of the adsorption process. For instance, $\mathrm{PVP}_{25}$ adsorption presented a positive $\Delta S^{0}$ value, which is a favorable degree of freedom expressed by randomness increment, also indicates that the adsorption leads to order through the formation of activated complex [27], suggesting that $\mathrm{Cu}(\mathrm{II})$ adsorption onto $\mathrm{PVP}_{25}$ surface is an associated mechanism. However, $\mathrm{PVP}_{2}$ and chitosan showed negative values, which usually reflects that no significant change occurs in the internal structure of the adsorbent during the adsorption process.

\section{Kinetics of the Heterogenization of $\mathrm{Cu}$ (II) Catalysts}

The adsorption data were used to examine the rate of the heterogenization process. Normally, the pseudo-first-order equation was expressed in the first contact time; on this period, the adsorption is highly favorable because the surface of the supports has great availability of energetic sites. The pseudo-first-order, generally applicable over the initial stage of adsorption processes, was based on the adsorption capacity and was expressed as (Eq. 10) [29]: 
Table 5. Kinetic adsorption rate constant $\left(k_{1}\right)$ and theoretical adsorption capacity $\left(q_{\mathrm{c}}^{*}\right)$ of $\mathrm{Cu}(\mathrm{II})$ onto $\mathrm{PVP}_{2}, \mathrm{PVP}_{25}$, chitosan. $[\mathrm{Cu}(\mathrm{II})]_{0}=0.1-1.0 \mathrm{~g} \mathrm{~L}^{-1}$ for $\mathrm{PVP}_{2}$ and $\mathrm{PVP}_{25},[\mathrm{Cu}(\mathrm{II})]_{0}=0.01-$ $0.10 \mathrm{~g} \mathrm{~L}^{-1}$ for chitosan, $m=1 \mathrm{~g}, T=20,30$, and $40^{\circ} \mathrm{C}$.

\begin{tabular}{lcc}
\hline Support & $\begin{array}{c}\text { Temperature } \\
(\mathbf{C})\end{array}$ & $\boldsymbol{k}_{\mathbf{1}}\left(\mathbf{m i n}^{-\mathbf{1}}\right)$ \\
\hline $\mathrm{PVP}_{2}$ & 20 & $2.3 \times 10^{-2} \pm 2 \times 10^{-3}$ \\
& 30 & $1.2 \times 10^{-2} \pm 2 \times 10^{-3}$ \\
$\mathrm{PVP}_{25}$ & 40 & $0.9 \times 10^{-2} \pm 2 \times 10^{-3}$ \\
& 20 & $2.6 \times 10^{-2} \pm 2 \times 10^{-3}$ \\
& 30 & $1.1 \times 10^{-2} \pm 6 \times 10^{-3}$ \\
Chitosan & 40 & $0.8 \times 10^{-2} \pm 9 \times 10^{-3}$ \\
& 20 & $2.2 \times 10^{-2} \pm 2 \times 10^{-3}$ \\
& 30 & $2.7 \times 10^{-2} \pm 4 \times 10^{-3}$ \\
& 40 & $3.9 \times 10^{-2} \pm 5 \times 10^{-3}$ \\
\hline
\end{tabular}

$\frac{d q}{d t}=k_{1} \cdot\left(q_{\mathrm{e}}-q\right)$

where the adsorption capacity $\left(q_{\mathrm{e}}\right)$ of the support at the equilibrium $\left(\mathrm{mg} \mathrm{g}^{-1}\right)$ and the pseudo first-order rate $k_{1}$ constant $\left(\mathrm{min}^{-1}\right)$ were related, then Eq. 10 becomes into Eq. 11 [29]:

$q_{t}=q_{\mathrm{e}}\left(1-e^{-k_{1} t}\right)$

Additionally, for adsorption isotherms, it exist the possibility to follow the pseudo-second-order behavior, which was represented by two-step linear relationships [29].

Pseudo-first and second order models were applied; however, the three of the tested materials fitted well with the pseudo-first rate model. Table 5 lists the adsorption rate constants of $\mathrm{PVP}_{2}, \mathrm{PVP}_{25}$, and chitosan polymers, it is evident the increment of the constant rate for chitosan, while decreases for $\mathrm{PVP}_{2}$ and $\mathrm{PVP}_{25}$.

The decrease of the rate constant was due to the reduction of colliding molecules when temperature increases. For the case of chitosan with a slight increment on the constant rate when temperature increases, suggests that temperature promotes the entropy of the system with the excitement of $\mathrm{Cu}(\mathrm{II})$ ions, to finally increase the rate constant values.

\section{Catalytic Testing of the Heterogeneous $\mathrm{Cu}$ (II) Catalysts}

The catalytic oxidation of phenol was performed using $\mathrm{PVP}_{2}$-Cu(II), $\mathrm{PVP}_{25} \mathrm{Cu}(\mathrm{II})$, and chitosan-Cu(II). The optimum catalyst was selected taking into account its catalytic activity in the reaction and its deactivation, mainly caused by the leaching of $\mathrm{Cu}(\mathrm{II})$.

Figure 9 shows the conversion of phenol and the leaching obtained along the reaction time at $\mathrm{pH}$ free. Figure 9 a shows that $\mathrm{PVP}_{2}-\mathrm{Cu}(\mathrm{II})$ and $\mathrm{PVP}_{25} \mathrm{Cu}(\mathrm{II})$ obtain the same $20 \%$ of conversion while chitosan-Cu(II) achieves 36\%. From these results, the suitable catalyst for the process is chitosan-Cu(II); however, experimentally it was observed that chitosan was destroyed after $15 \mathrm{~min}$, releasing its $\mathrm{Cu}(\mathrm{II})$ content to the reaction media, therefore being excluded as a suitable catalyst. The comparison between leaching of $\mathrm{PVP}_{2}-\mathrm{Cu}(\mathrm{II})$ and $\mathrm{PVP}_{25}-\mathrm{Cu}$ (II) demonstrated that $\mathrm{PVP}_{2}-\mathrm{Cu}(\mathrm{II})$ had $5 \mathrm{mg} \mathrm{L}^{-1}$ of leaching, which is an acceptable value for the pretreatments with metals [38]. As a result, $\mathrm{PVP}_{2}$-Cu(II) was selected as the best catalyst for the oxidation of phenol at soft conditions.

Additionally and after the selection of $\mathrm{PVP}_{2}-\mathrm{Cu}(\mathrm{II})$ as catalysts, it was evaluated the influence of temperature over the oxidation of phenol when using $\mathrm{PVP}_{2}-\mathrm{Cu}(\mathrm{II})$ as catalyst. Three temperatures were tested $\left(30,40\right.$ and $\left.50^{\circ} \mathrm{C}\right)$ and the $\mathrm{pH}$ was fixed to $\mathrm{pH} 6$ to avoid Cu(II) leaching.

On Figure 10 was observed the results of phenol conversion, it is clear the influence of temperature over the reac-
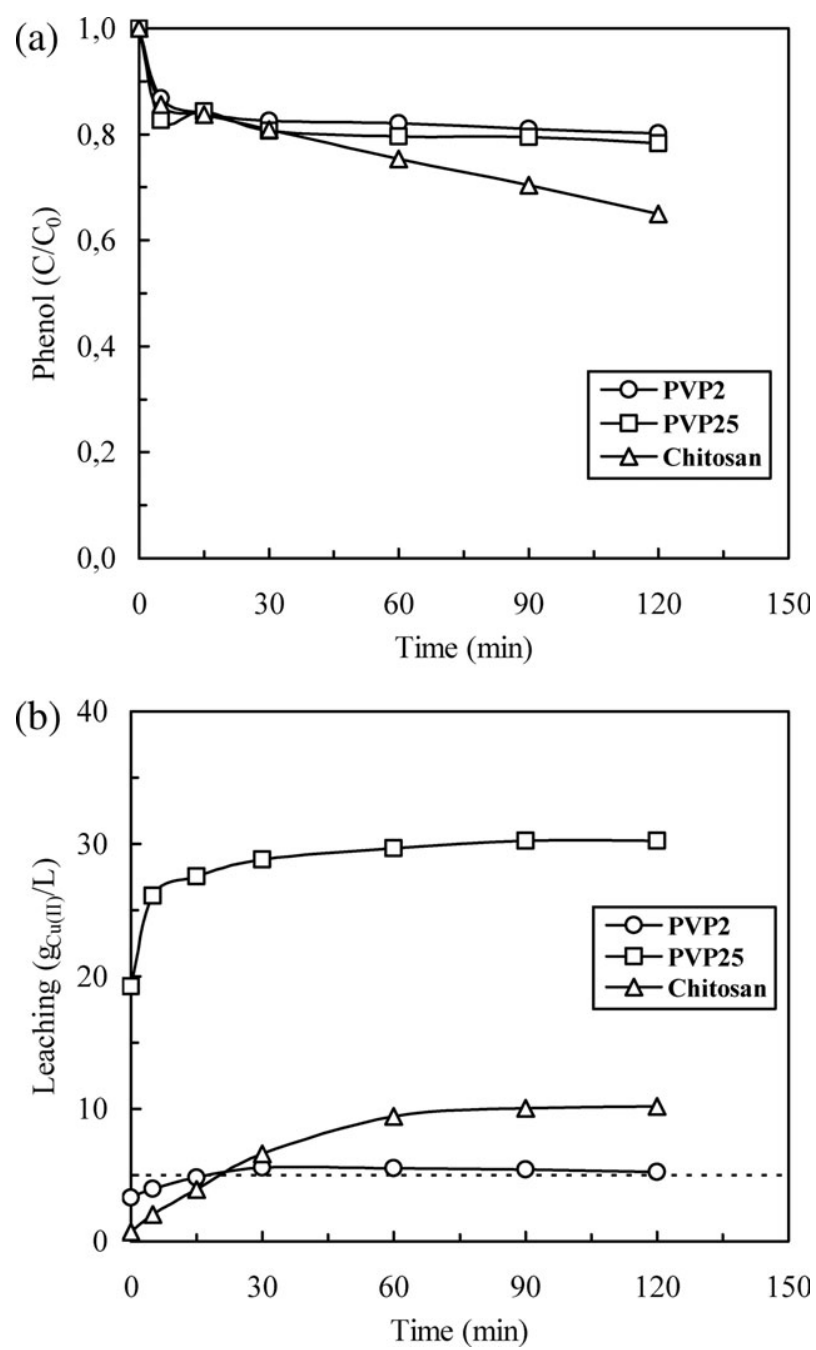

Figure 9. Heterogeneous catalytic phenol oxidation: Influence of the polymer-Cu(II) catalyst with the equivalent to 50 $\mathrm{mg} \mathrm{L}^{-1}$. (a) Phenol conversion and (b) Leaching. $[\mathrm{Ph}]_{0}=1 \mathrm{~g}$ $\mathrm{L}^{-1}, \mathrm{Ph}: \mathrm{H}_{2} \mathrm{O}_{2} 1: 14$ molar ratio, time $=2 \mathrm{~h}$ at free $\mathrm{pH}, 30^{\circ} \mathrm{C}$ and atmospheric pressure.

tion, up to $64 \%$ of phenol conversion at $50^{\circ} \mathrm{C}$. Considering the metal leaching of the catalyst, it was observed that at $\mathrm{pH}$ 6 the leaching has decreased, but $\mathrm{Cu}(\mathrm{II})$ release at $50^{\circ} \mathrm{C}$ cross the limit $\left(5 \mathrm{mg} \mathrm{L}^{-1}\right)$ of acceptable metal contamination for industrial effluents. Thereafter, it was suggested the use of $\mathrm{PVP}_{2}-\mathrm{Cu}(\mathrm{II})$ as catalyst of the wet peroxide oxidation of phenol at $\mathrm{pH} 6,40^{\circ} \mathrm{C}$ and atmospheric pressure.

\section{CONCLUSIONS}

The heterogenization of $\mathrm{Cu}(\mathrm{II})$ as catalyst for the oxidation of phenol was effectively conducted and the performances obtained are promising for its industrial utilization as pretreatment for industrial wastewater. Among the polymer$\mathrm{Cu}(\mathrm{II})$ catalyst tested, $\mathrm{PVP}_{2}$-Cu(II) catalyst was selected as the most suitable catalyst for the process. This catalyst did not suffer destruction during the reaction period and its metal leaching was low and acceptable for the industrial wastewater $\left(5 \mathrm{mg} \mathrm{L}^{-1}\right)$. The catalyst was tested at 40 and $50^{\circ} \mathrm{C}$ where phenol conversions up to $64 \%$ were obtained; however, it was recommended to work at $40^{\circ} \mathrm{C}$ to prevent leaching problems, allowing the possibility to work in continue and avoiding the necessity to remove the copper in solution. 

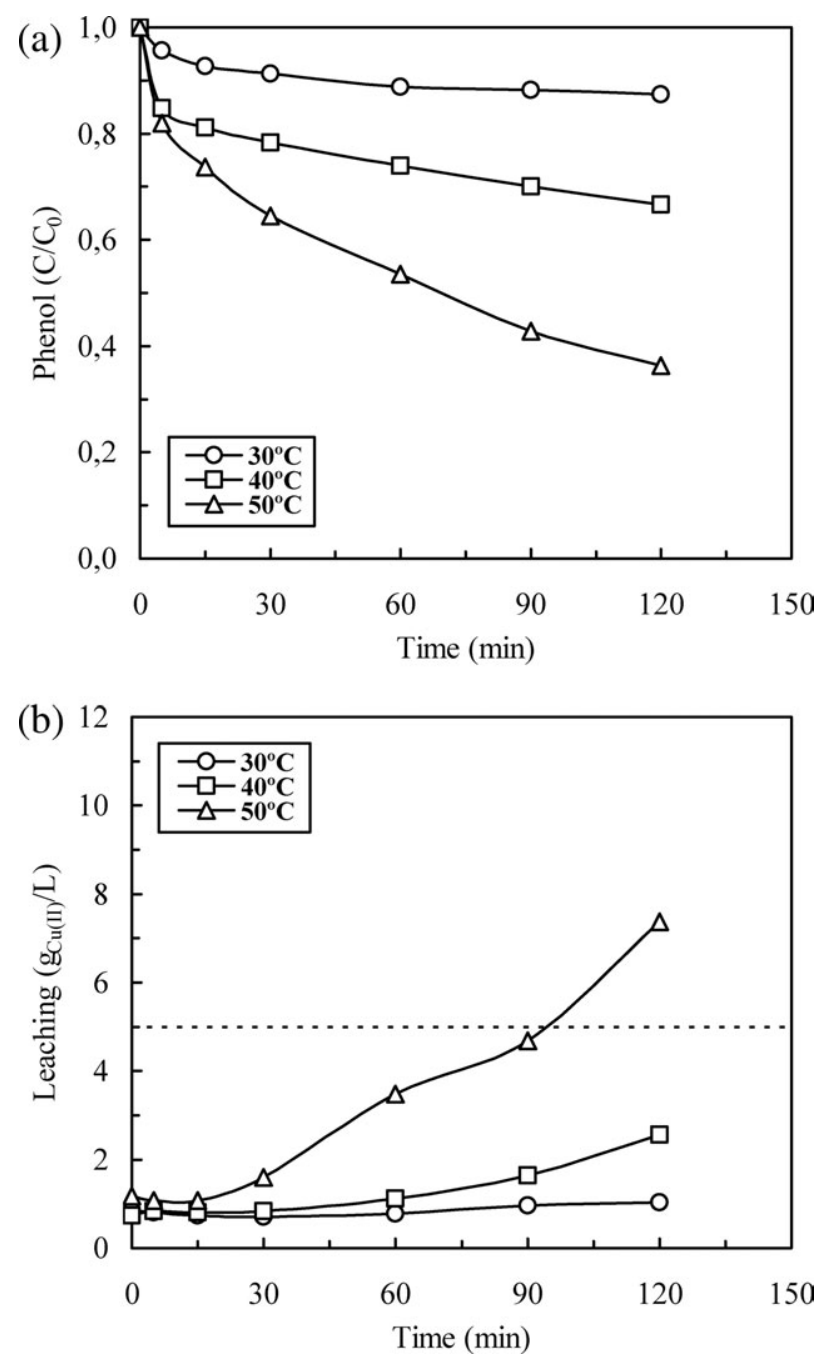

Figure 10. Heterogeneous catalytic phenol oxidation: Influence of the temperature $\left(30,40\right.$, and $\left.50^{\circ} \mathrm{C}\right)$ when using $\mathrm{PVP}_{2}$-Cu(II) as catalysts $0.45 \mathrm{~g}$ equivalent to $50 \mathrm{mg} \mathrm{L}^{-1}$ of $\mathrm{Cu}(\mathrm{II})$ in solution. (a) Phenol conversion and (b) Leaching. $[\mathrm{Ph}]_{0}=1 \mathrm{~g} \mathrm{~L}^{-1}, \mathrm{Ph}: \mathrm{H}_{2} \mathrm{O}_{2}$ 1:14 molar ratio, time $=2 \mathrm{~h}$ at $\mathrm{pH}$ 6 and atmospheric pressure.

From the study of the properties of the catalysts, FTIR analysis described the differences between PVPs, where the crosslinking degree of polymers characterize their structural molecules and surface activity. The crosslinking degree, $\mathrm{pH}$, and temperature influenced the heterogenization of $\mathrm{Cu}(\mathrm{II})$, especially for $\mathrm{PVP}_{2}$ case. It has the lowest crosslinking degree and proved to get the highest $q$ at acid $\mathrm{pH}$ and high temperatures, up to $90 \mathrm{mg} \mathrm{g}^{-1}$ of $\mathrm{Cu}(\mathrm{II})$ at $40^{\circ} \mathrm{C}$.

Langmuir and Freundlich models were applied to the experimental data to characterize the adsorption process. From these models, it was observed that the polymers under study present surfaces with different energetic and well organized areas where $\mathrm{Cu}(\mathrm{II})$ was attached. Even more, this behavior remains similar when temperature varied.

The kinetics of the heterogenization of $\mathrm{Cu}$ (II) describes the process by the pseudo-first rate model, which at the same time was recognized as a physisorption process. This type of adsorption highly impulses the use of heterogeneous Cu(II) catalysts, on the oxidation of phenol, because the physisorption preserves the catalytic activity of the homogeneous $\mathrm{Cu}(\mathrm{II})$ catalyst in a heterogeneous form.

\section{ACKNOWLEDGMENTS}

Financial support for this research was provided in part by the Spanish Ministerio de Educación y Ciencia, project "CTM2005-01873." Isabel U. Castro is indebted to the Universitat Rovira i Virgili for providing a predoctoral scholarship.

\section{LITERATURE CITED}

1. Caudo, S., Centi, G., Genovese, C., \& Perathoner, S. (2007). Copper- and iron-pillared clay catalysts for the WHPCO of model and real wastewater streams from olive oil milling production, Applied Catalysis B: Environmental, 70, 437-446.

2. Fajerwerg, K., \& Debellefontaine, H. (1996). Wet oxidation of phenol by hydrogen peroxide using heterogeneous catalysis Fe-ZSM-5: A promising catalyst, Applied Catalysis B: Environmental, 10, L229-L235.

3. Luo, M., Bowden, D., \& Brimblecombe, P. (2009). Catalytic property of Fe-Al pillared clay for Fenton oxidation of phenol by $\mathrm{H}_{2} \mathrm{O}_{2}$, Applied Catalysis B: Environmental, 85, 201-206.

4. Ramirez, J.H., Costa, C.A., Madeira, L.M., Mata, G., Vicente, M.A., Rojas-Cervantes, M.L., López-Peinado, M.J., \& Martín-Aranda, R.M. (2007). Fenton-like oxidation of Orange II solutions using heterogeneous catalysts based on saponite clay, Applied Catalysis B: Environmental, 71, 44-56.

5. Zazo, J.A., Casas, J.A., Mohedano, A.F., \& Rodríguez, J.J. (2006). Catalytic wet peroxide oxidation of phenol with a Fe/active carbon catalyst, Applied Catalysis B: Environmental, 65, 261-268.

6. Garin, F. (2004). Environmental catalysis, Catalysis Today, 89, 255-268.

7. Gupta, K.C., \& Sutar, A.K. (2008). Polymer supported catalysts for oxidation of phenol and cyclohexene using hydrogen peroxide as oxidant, Journal of Molecular Catalysis A, 280, 173-185.

8. Lázaro-Martinez, J.M., Leal, M.F., Piehl, L.L., Rubín, E., Buldain, G.Y., \& Campo, V. (2008). Studies on the activation of hydrogen peroxide for colour removal in the presence of a new Cu(II)-polyampholyte heterogeneous catalyst, Applied Catalysis B: Environmental, 82, 273-283.

9. Barrault, J., Abdellaoui, M., Bouchoule, C., Majesté, A., Tatibouet, J.M., Louloudi, J., Papayannakos, N., \& Gangas, N.H. (2000). Catalytic wet peroxide oxidation over mixed (Al-Fe) pillared-clays, Applied Catalysis B: Environmental, 27, L225-L230.

10. Sheldon, R.A., \& Downing, R.S. (1999). Heterogeneous catalytic transformations for environmentally friendly protection, Applied Catalysis A: General, 189, 163-183.

11. Mocioi, M., Albu, A.M., Mateescu, C., Voicu, G., Rusen, F., Marculescu, B., \& Mutihac, L. (2007). New polymeric structures designed for the removal of $\mathrm{Cu}(\mathrm{II})$ ions from aqueous solution, Journal of Applied Polymer Science, 103, 1397-1405.

12. Wan-Ngah, W.S., Endud, C.S., \& Mayanar, R. (2002). Removal of copper(II) ions from aqueous solution onto chitosan and cross-linked chitosan beads, Reactive and Functional Polymers, 50, 181-190.

13. Pestunova, O.P., Ogorodnikova, L., \& Parmon, V.N. (2003). Studies on the phenol wet peroxide oxidation in the presence of solid catalysts, Chemistry for Sustainable Development, 11, 227-232.

14. Saha, B., \& Streat, M. (2005). Adsorption of trace heavy metals: Application of surface complexation theory to a macroporous polymer and a weakly acidic ion-exchange resin, Industrial \& Engineering Chemistry Research, 44, 8671-8681.

15. Chu, K.H. (2002). Removal of copper from aqueous solution by chitosan in prawn shell: Adsorption equilibrium kinetics, Journal of Hazardous Materials, 90, 77-95. 
16. Kucherov, A.V., Kramareva, N.V., Finashina, E.D., Koklin, A.E., \& Kustov, L.M. (2003). Heteronized redox catalysts on the basis of chitosan matrix. 1. Copper complexes, Journal of Molecular Catalysis A, 198, 377-389.

17. Syukri, S., Hijazi, A.K., Sakthivel, A., Al-Hmaideen, A.I., \& Kühn, F.E. (2007). Heterogenisation of solvent-ligated copper(II) complexes over poly(4-vinylpyridine) for the catalytic cyclopropanation of olefins, Inorganica Chimica Acta, 360, 197-202.

18. Yamashita, K., Okada, L., Suzuki, Y., \& Tsuda, K. (1988). Poly(4-vinyl-piridine-co-N-vinyl pyrrolidone)-Cu(II) complex, highly active polymeric complex catalyst for the hydroquinone oxidation, Makromolekulare Chemie, Rapid Communications, 9, 705-708.

19. Yamashita, K., Kanamori, T., Nango, M., \& Tsuda, K. (1993). The oxidation of hydroquinone catalysed by poly(4- vinyl-piridine-co-N-vinyl pyrrolidone)-Cu(II) complexes: Effect of the copolymer composition, distribution on the catalytic activity, Polymer, 34, 2638-2643.

20. Dioos, B.M.L., Vankelecom, I.F.J., \& Jacobs, P.A. (2006). Aspects of immobilization of catalysts on polymeric supports, Advanced Synthesis \& Catalysis, 348, 1413-1446.

21. Guibal, E. (2005). Heterogeneous catalysis on chitosanbased materials: A review, Progress in Polymer Science, 30, 71-109.

22. Guibal, E., Milot, C., \& Tobin, J.M. (1998). Metal-anion sorption by chitosan beads: Equilibrium and kinetics studies, Industrial \& Engineering Chemistry Research, 37, 1454-1463.

23. Perkin-Elmer Corporation. (1994). Analytical Methods for atomic absorption spectrometry. Norwalk: Perkin-Elmer Corporation.

24. Kumaresan, R., Sabharwal, K.N., Srinivasan, T.G., Vasudeva, P.R., \& Dhekane, G. (2008). Studies on the sorption of palladium using cross-linking poly(4-vynilpyridine-divinylbenzene) resins in nitric acid medium, Solvent Extraction and Ion Exchange, 26, 643-671.

25. Wu, K.H., Wang, Y.R., \& Hwu, W.H. (2003). FTIR and TGA studies of poly(4-vinylpyridine-co-divinylbenzene)Cu(II) complex, Polymer Degradation and Stability, 79, 195-200.

26. Srivastava, A., \& Srivastava, P.C. (1990). Adsorption-desorption behaviour of zinc(II) at iron(III) hydroxideaqueous solution interface as influenced by $\mathrm{pH}$ and temperature, Environmental Pollution, 68, 171-180.

27. Dogan, M., Abak, H., \& Alkan, M. (2009). Adsorption of methylene blue onto hazelnut shell: Kinetics, mechanism and activation parameters, Journal of Hazardous Materials, 164, 172-181.

28. Verbych, S., Bryk, M., Chomokur, G., \& Fuhr, B. (2005). Removal of copper(II) from aqueous solutions by chitosan adsorption, Separation Science and Technology, 40, 1749-1759.

29. Ahmad, A.L., Sumathi, A.S., \& Hameed, B.H. (2005). Adsorption of residue oil from palm oil mill effluent using powder and flake chitosan: Equilibrium and kinetics studies, Water Research, 39, 2483-2494.

30. Li, N., \& Bai, R. (2005). A novel amine-shielded surface cross-linking of chitosan hydrogel beads for enhanced metal adsorption performance, Industrial \& Engineering Chemistry Research, 44, 6692-6700.

31. Langmuir, I. (1916). The constitution and fundamental properties of solids and liquids. Part I. Solids, Journal of the American Chemical Society, 38, 2221-2295.

32. Wan-Ngah, W.S., Ab, S., \& Kamari, A. (2005). Adsorption behaviour of $\mathrm{Fe}$ (II) and $\mathrm{Fe}(\mathrm{III})$ ions in aqueous solution on chitosan and cross-linked chitosan beads, Bioresource Technology, 96, 443-450.

33. Wan, M., Petrisor, I.G., Lai, H.T., Kim, D., \& Yen, T.F. (2004). Copper adsorption through chitosan immobilized on sand to demonstrate the feasibility for in situ soil decontamination, Carbohydrate Polymers, 55, 249-254.

34. Demirbas, E., Dizge, N., Sulak, M.T., \& Kobya, M. (2009). Adsorption kinetics and equilibrium of copper from aqueous solution using hazelnut shell activated carbon, Chemical Engineering Journal, 148, 480-487.

35. Weng, C.H., Tsai, C.Z., Chu, S.H., \& Sharma, W.C. (2007). Adsorption characteristics of $\mathrm{Cu}(\mathrm{II})$ onto spent activated clay, Separation and Purification Technology, 54, 187-197.

36. Tan, I.A.W., Amat, A.L., \& Hameed, B.H. (2009). Adsorption isotherms, kinetics, thermodynamics and desorption studies of 2,4,6-trichlorophenol on oil palm empty fruit bunch-based activated carbon, Journal of Hazardous Materials, 164, 473-482.

37. Boujelben, N., Bouzid, J., \& Elouear, Z. (2009). Adsorption of nickel and copper onto natural iron oxide-coated sand from aqueous solutions: Study in a single and binary systems, Journal of Hazardous Materials, 163, 376382.

38. Law 10/1993 of Industrial Effluents. (1993). Ley sobre vertidos industriales al sistema integral de saneamiento, Servicio de coordinación legislativa y relaciones institucionales. October 26th, Spain. 